\author{
Leszek Kopciuch \\ Maria Curie-Skłodowska University, Lublin, Poland \\ ORCID: 0000-0001-9128-697X \\ e-mail: leszekkopciuch@poczta.umcs.lublin.pl
}

DOI: http://dx.doi.org/10.12775/RF.2021.023

\title{
Crisis of Values: a Critical Analysis
}

The term 'crisis of values', though extremely popular from the beginning of the twentieth century ${ }^{1}$ and now commonly used in public discourse, ${ }^{2}$ seems to pose several theoretical problems, because it is so broad that it is easy to misinterpret or apply it to an area where it no longer belongs. In addition, both keywords - crisis and values - are rather ambiguous, and loaded with various historical meanings. In the following considerations, four selected levels will be outlined where some doubts can be raised about a crisis of values: (i) Should we speak of a crisis of values or a crisis of the consciousness of values? (ii) Should we speak of a crisis of values or a crisis of a certain type of value? (iii) Is a possible crisis of values (no matter how construed) only a negative phenomenon, or can it also be a positive event? (iv) Are crises of values brewing in the consciousness of

1 For example: Oswald Spengler, Der Untergang des Abendlandes; Florian Znaniecki, Upadek cywilizacji zachodniej. Szkic z pogranicza filozofii kultury i socjologii; Edmund Husserl, Die Krisis der Europäischen Wissenschaften und die Transzendentale Phänomenologie; Edmund Husserl, Die Krisis des europäischen Menschentums und die Philosophie; Pitirim Sorokin, The Crisis of Our Age. The Social and Cultural Outlook; Reinhold Niebuhr, The Cultural Crisis of Our Age; José Ortega y Gasset, La rebelión de las masas.

2 For example: James P. Thrasher, A Crisis of Values: Moving from Materialism to Reality (Michigan: Michigan University, 1985); Jay Blumler, Michael Gurevitch, The Crisis of Public Communication (London: Routledge, 1995); Wayne E. Baker, America's Crisis of Values: Reality and Perception (Princeton: Princeton University 
the ordinary person immersed in ordinary life situations more dangerous than crises arising in theories, in the conceptions of which they are proposed? The aim of these considerations is, on the one hand, to specifically define the terminology without which it is difficult to imagine a proper description of events in culture referred to as a crisis of values. On the other hand, it is necessary to establish whether we are experiencing a crisis of values and, if so, what its nature is.

\section{A crisis of values or a crisis of the consciousness of values?}

You can speak of a crisis of values in manifold perspectives. The first of them, still very broad, is the formal perspective. By accepting it, we do not ask what specific values are in crisis, but only whether the values themselves are in crisis. To answer this question in the affirmative, certain conditions must be met. These are, however, antinomic conditions, i.e. such that although they are mutually contradictory, they are all required to be met if we are to speak of a crisis of values: (i) Values must be understood as time objects, i.e. existing in time and subject to its influence. (ii) Values must be understood as extratemporal objects; although they somehow realise themselves in time, they also exist beyond these realisations. The first condition must be met if we are to recognise that so fundamental a change has taken place in values that we must call it a crisis. If values were immutable, they could not 'degenerate' into crises. The second condition must be met if we are to recognise that the change is a variant of a crisis. In other words, there must be a norm or a standard, a deviation from which constitutes a crisis.

Press, 2005); Jacek Breczko, “Zanik uczuć metafizycznych jako przyczyna kryzysu kultury", Kultura i Wartości 13 (2015): 39-73, https://journals.umcs.pl/kw/article/ view/1715/1340, accessed: 20.05.2021; Marek J. Calinski, Crisis and Renewal of Civilizations: the $21^{\text {st }}$ Century Crisis of Ideas and Character (New York: Nova Publishers, 2015); Malina Voicu, Ingvill C. Mochmann, Hermann Dülmer (eds.), Values, Economic Crisis and Democracy (London-New York: Routledge, 2016); Mark Greif, The Age of the Crisis of Man; Thought and Fiction in America, 1933-1973 (Princeton: Princeton University Press, 2016); Adam Nobis, “The New Silk Road as a Crisis of the Value of Globalization", Kultura i Wartości 25 (2018): 9-24, doi: 10.17951/ kw.2018.25.9; Tomasz Stefaniuk, “Does Mass Culture Mean a Crisis of Values? Dwight Macdonald's Position and the Issue of Its Topicality", Kultura $i$ Wartości 25 (2018): 25-51, doi: 10.17951/kw.2018.25.25; Elżbieta M. Goździak, Izabella Main, Brigitte Suter (eds.), Europe and the Refugee Response: A Crisis of Values? (London: Routledge, 2020). 
Can you think of a consistent combination of both conditions? Not in the strict sense. However, you can make some modification that will make this combination possible. This modification may consist in the fact that instead of speaking of a crisis of values alone, we will speak of a crisis in our perception, not of a crisis of values alone, but of a crisis of the consciousness of values. Hence, values themselves are not subject to change nor a crisis change. That which is subject to change is only our knowledge about values, our attitudes built on them, our choices based on them.

The situation is somewhat paradoxical. It implies that those who cannot speak of it can speak of a crisis of values. In order to identify a crisis of values, I must assume that values themselves, as a norm or a standard, are beyond the level at which crises occur.

But there is another doubt about this level. If a human being is a teleological being, then this fact means that he or she can by no means function without reference to values - as a human being, i.e. as a creature that performs specifically human activities. The teleological structure of human action implicitly assumes value as a condition of the goal: for my goal I choose what I consider to be valuable, and among the various possible goals I choose - the one I think is the most valuable. This also happens when I choose wrongly, when I get stuck in illusions and do not have the correct knowledge of values. This shows that, in fact, also in this case, the whole thing does not concern values, but our knowledge about them. Also, looking at things from this vantage point, it is possible to replace the value level with our knowledge of values. Of course, this does not mean that we reduce one level to another. We need values themselves to be able to discern between correct and incorrect axiological knowledge; regardless of whether the value status is independent of our knowledge, we will interpret it in a metaphysical or only epistemological fashion.

The approach presented above may be supported by views which, in this respect, were formulated in the history of philosophy. Nicolai Hartmann's axiology is particularly illustrative here. Arguing against the relativistic interpretation of values, Hartmann discriminated between value and its validity and, as a result, drew the conclusion that the relativism of values does not actually relate to values themselves, but only to their validity in culture and ethos. ${ }^{3} \mathrm{~A}$ similar type of antirelativist reasoning is popular among other philosophers. For example, Polish theoretician

3 Cf. Nicolai Hartmann, "Das Wertproblem in der Philosophie der Gegenwart", in: Nicolai Hartmann, Kleinere Schriften, Bd. 3: Vom Neukantianismus zur Ontologie (Berlin: Walter de Gruyter \& Co., 1958), 327-333. 
Kazimierz Twardowski argued that since there are manifold views on good in different epochs or cultures, we cannot conclude about the relativity of good itself. Such diversity may have a source in the immaturity or misidentification of values. ${ }^{4}$ Similar reasoning is also presented in the ethical and axiological considerations of Władysław Tatarkiewicz. ${ }^{5} \mathrm{He}$ wrote that the alleged relativity of good is sometimes confused with its unavailability for some people; sometimes a limited human mind cannot comprehend too many goods at the same time.

The fact that there are philosophers who explicitly or implicitly use the distinction between values themselves and the consciousness of values by no means proves that this distinction is correct. An axiological subjectivist or relativist can always say that such a distinction is sterile, because it remains based on the assumption that something like values other than the consciousness of values exists at all. If I equate values with the survival of values (i.e. with the consciousness of values) in a 'subjective way', then only this consciousness of values will survive. Thus, it may be conjectured that this distinction can in fact be used sensibly only by proponents of axiological objectivism or relationalism. I think that, on the one hand, such a supposition would be premature. If values, therefore, have no being in themselves, and what exists is only experiencing them (i.e. the consciousness of values), then a crisis of whatsoever type can be lodged only at the level of the consciousness of values. On the other hand, one cannot fail to notice that a subjectivist or relativistic discernment of values may be problematic if we attempt to speak of a crisis within the extent of such a construction, because a crisis presupposes the existence of criteria other than experience or consciousness of values. A crisis of values is a crisis of values, not a crisis of the consciousness of values. Only such criteria will make it possible to distinguish a deviation from the norm (a normal condition other than a crisis).

4 Cf. Kazimierz Twardowski, "Etyka a teoria ewolucji”, in: Kazimierz Twardowski, Etyka (Toruń, Wydawnictwo Adam Marszałek, 1994), 115-117. See also: Józef Dębowski, "On Absolute Truth: K. Twardowski and W. Tatarkiewicz", in: Polish Axiology; The 20 $0^{\text {th }}$ Century and Beyond, ed. Stanisław Jedynak (Washington: The Council for Research in Values and Philosophy, 2005), 95-121.

5 Cf. Władysław Tatarkiewicz, "O bezwzględności dobra” [On the Absoluteness of the Good], in: Władysław Tatarkiewicz, Droga do filozofii (Warszawa: PWN, 1971), 246. See also: Anna Drabarek, "The Conception of Goodness in Tatarkiewicz's Ethics", in: Polish Axiology; The $20^{\text {th }}$ Century and Beyond, 154, 155-156. 


\section{A crisis of value in general or a crisis of a particular type of value?}

We have just spoken of values in a very general way without exploring their diversity. And yet in the diversity of our life situations, values appear as different or diverse according to their types and within their own realms. Consequently, we can speak of moral, religious, social, intellectual, vital, hedonic values, etc. Just like within the realm of moral values, we can speak of such values as honesty, trustworthiness, truthfulness, faithfulness, etc. and within hedonic values, such values as pleasure, satisfaction, enjoyment, delight, physical pleasure, mental pleasure etc.

Such a diversity should be properly understood. The heterogeneity of values does not mean that they are of equal rank. On the contrary, there can be superior or inferior values, such as are more or less valuable, more or less worthy of choice and realisation. Such diverse values acquire meaning and relevance under specific cultural conditions. Even Aristotle emphasised in his meticulous ethics of moderation that bravery is recognised as a virtue in the face of danger. If it is so that different cultural factors entail concentration on a particular type of value - according to the regularities discussed in the Ethics by Nicolai Hartmann ${ }^{6}$ - it may mean that so-called value crises are de facto crises of certain types of values.

This material perspective therefore argues that values are specific, concrete cultural senses. A crisis of values is then a loss of meaning that these particular types of values in culture possess. Consequently, one can speak of a crisis which, in the contemporary mass culture, a value of productive life experiences while it is being superseded by a value of consumer life. By the same token, one can speak of a crisis of a value of personhood (subjectivity) in totalitarian societies, or of a crisis of values of solidarity in societies based on economic competition.

It is quite striking that reference to a crisis of values - values conceived as cultural meanings - comes into prominence when we consider higher, superior values. In fact, there are no theories that describe the crisis of values and understand this crisis as a crisis of hedonic values. There are no such theories of crisis, if 'crisis' implies endangering values and the disappearance of their validity and power to influence real human attitudes and actions. It is rather the other way round: thriving hedonism is a symptom of a crisis of values. A more or less similar conclusion will be reached in the case of utilitarian values, exemplified by the views of

6 Cf. Nicolai Hartmann, Ethik, 4. unveränderte Auflage (Berlin: Walter de Gruyter \& Co., 1962), 36-71, 138-147. 
Pitirim Sorokin, who treated the domination of a sensate supersystem as an expression of the cultural crisis. ${ }^{7}$ An analogous view is expressed by Stanisław Ignacy Witkiewicz, who confronted metaphysical values (truth and beauty) with moral values discerned in a utilitarian fashion, and who interpreted the dominance of utilitarian values first as a manifestation of crisis, and then as an end to real humanity. ${ }^{8}$

But this conclusion intimates a mere 'more or less' type of similarity. With respect to utilitarian values, there are, however, some important differences. First of all, lack of utility can also be experienced as a crisis. That lack is normally expressed in language when we speak of the futility of action, the uselessness of a tool, the inefficiency of policy, the ineffectiveness of action, the ineffectiveness of industrial production, or the uncompetitive nature of economy. One more thing is important here namely, it seems inevitable that in developing cultural systems, the tools or technological solutions must lose their utilitarian value when they are supplanted by other, more economical or efficient ones. Such a crisis (conceived as an element of developmental and progressive movement) seals the doom of obsolescent tools and technologies.

Regardless of the above-mentioned theorists' opinions, you can say that it is not the thriving of lower values that is the expression of a crisis. The thriving of lower values may co-exist with the flourishing of other values; I do not think it is incapable of achievement. There may be lots of various flowers blooming in the meadow. If we are to speak of a crisis of values, a lower group of values must flourish at the expense of a group of higher values, either by diminishing social sensitivity to them or by completely eliminating them. The severity of a crisis of values is affected by the reduction of or encroachment upon the realm of higher values. The greater the encroachment, the more severe the crisis. This is aptly illustrated by hedonism. This position is monistic because here value is reduced to pleasure. When discussing pleasure, Aristotle invokes a hedonistic view according to which pleasure is the supreme good. Such a definition of hedonism is not very felicitous. Other, inferior goods may be non-hedonic.

7 Cf. Marek Wichrowski, Historiozofia Pitirima Sorokina, PhD thesis (typescript in the archives of the Department of the History of Philosophy and Comparative Philosophy, Maria Curie-Skłodowska University in Lublin).

8 Cf. Stanisław Ignacy Witkiewicz, Nowe formy $w$ malarstwie $i$ wynikajace stad nieporozumienia, in: Stanisław Ignacy Witkiewicz, Nowe formy w malarstwie. Szkice estetyczne. Teatr, ed. J. Leszczyński (Warszawa: PWN, 1974), 13-180. Cf. also Breczko, "Zanik uczuć metafizycznych jako przyczyna kryzysu kultury": 39-73; Zofia Rosińska, "Recognising Crisis in Culture”, Kultura i Wartości 17 (2016): 5-25, doi: 10.17951/kw.2016.17.5. 
The correct definition of hedonism, also presented by Aristotle, says that pleasure is the only good. Hedonism is not a manifestation of a crisis of values because it prefers the value of pleasure but because it excludes other possible non-hedonistic types of values. This is so because it overlooks the nature of pleasure. This line of thought has been pursued in the history of philosophy since time immemorial. It was Aristotle who said (in Nicomachean Ethics) that human actions are complemented by pleasure. Moritz Schlick was close to the correct interpretation of this phenomenon when in Fragen der Ethik he wrote that the human goal is not to go after pleasure but after such a state of things as is accompanied by the idea of pleasure. ${ }^{9}$ Hans Reiner emphasised in this context that Schlick's hedonistic position differed from earlier forms of hedonism which held that pleasure was the natural goal of action. ${ }^{10}$ Recognising the validity of Reiner's conception, I think, however, that the idea that pleasure 'colours' human desires, making us desire at all, is not really a refinement of hedonism, but its denial: it can lead to the proposition that in addition to the value which has that which is desired there is a hedonic value that accompanies it. This would be a correct approach, but totally unacceptable to Schlick.

\section{Is a crisis of values - conceived strictly as a crisis of the consciousness of values - only a negative phenomenon, or can it also have a positive character?}

The answer to this question calls for a prerequisite definition of crisis itself and an indication of what types of crises are taken into account. We are speaking of a crisis of values conceived as a crisis of the consciousness of values. A moment of threat to something valuable, constitutive to any crisis, may mean that: (i) A value (a type of value) is not discerned at all. (ii) A value (a type of value) is recognised, but its rank and position are inadequately classified, for example, superior values are placed low and inferior values are placed high - in the sense in which Max Scheler spoke of 'values shifting' in contemporary consciousness, which consists in displaying utility values at the expense of vital values. (iii) A value (a type of value) as an element of human consciousness 'wears out' and loses its power to inspire human desires and actions and is consequently replaced

9 Cf. Moritz Schlick, Problems of Ethics, authorised translation by David Rynin (New York: Prentice-Hall, Inc., 1939), 36-41.

10 Cf. Hans Reiner, Die philosophische Ethik. Ihre Fragen und Lehren in Geschichte und Gegenwart (Heidelberg: Quelle \& Meyer, 1964), 40-46. 
by another, new value in the same sense as Jacob Burckhardt defined history as a process of the destruction of existing values and superseding them with other values, without interpreting these transformations in a progressive manner. ${ }^{11}$ (iv) A value (a type of value) wears out in the sense that it gives way to a different, superior form, as an element of a progressive process, for example, in the sense in which Hegel referred to ever higher historical forms of consciousness of freedom.

The above variants become clear in the light of three general types of crisis. I think that you can speak of crisis in the following three different senses of the word. (i) A crisis can be conceived as a period in which the transition from the lower to the higher form of a value takes place; the crisis is then part of a progressive process; a constructive and not a negative side of the crisis is then highlighted. Although the crisis destroys and annihilates, it does so to make room for something more valuable. (ii) A crisis can be conceived as a period during which what has been destroyed is replaced by something different - a new stage that is not more valuable than the earlier stage. The period before the crisis differs from the period after the crisis, but the later period does not ameliorate the earlier period. A certain complication in this variant may be the fact that what is new is valuable because it is new (the value of novelty is realised). ${ }^{12}$ Nevertheless, the value of novelty is not sufficient to warrant the progressivism, since it requires that the subsequent state be not only new but also better than the earlier state. (iii) A crisis can finally be conceived as a stage in which the 'burning out' of values occurs which founds a cultural totality, and this process represents its 'decline' and end. A crisis so discerned is an element of cultural destruction, whereas the theory of crisis is an element of the catastrophe theory. If you ignore the specific arguments deployed by Oswald Spengler, who tried to show that the catastrophe is optimistic, this position incorporates crisis into a pessimistic structure.

These different variants of crisis also 'radiate to' the axiological character of the crisis of values. This axiological character can be both negative and positive. This statement probably will not be accepted by everyone. During the Lublin conference A Crisis of Values? (November 2017), ${ }^{13}$ one

11 Cf. Jacob Burckhardt, Weltgeschichtliche Betrachtungen. Über geschichtliches Studium, in: Jacob Burckhardt, Weltgeschichtliche Betrachtungen. Historische Fragmente, ed. Johannes Wenzel (Leipzig: Dieterich'sche Verlagsbuchhandlung, 1985), 155-197.

12 I wrote about this axiological regularity in Kryzysy, kreatywność $i$ wartości (Lublin: Wydawnictwo UMCS, 2015), 159-165.

13 Cf. Leszek Kopciuch, "Crise of Values (Conference Report)", Kultura $i$ Wartości 24 (2017): 159-163, https://journals.umcs.pl/kw/article/view/7483/5671. 
of the attendees raised doubts regarding this matter: is this positive interpretation of crisis not an over-interpretation of the term; or is it rather that a crisis should be called a state that leads to something worse than the previous state? And further, does such a broad conception of crisis not mean that we may have to regard any change as a crisis? I will now repeat the arguments I used when giving my reply. Clearly, in all likelihood, not every change is preceded by a crisis; not every change should be called a crisis, i.e. a state that leads to an important transformation, affecting a constitutive moment, no matter whether it happens in an individual's life or in the socio-cultural dimension. A crisis does not have to lead to a worse condition; sometimes it will be a different state and sometimes an even more valuable state. Let us think about the crisis undergone by a teenager turning into an adult, or about a crisis during which, in the eighties, the Polish totalitarian state turned into a liberal state. The etymology of the term provides evidence that crisis can be an axiologically positive category; after all, the origin of the term 'crisis' has its roots in medical sciences where it means a critical point reached during an illness which may result in death or recovery.

\section{Are crises of values brewing in the consciousness of the ordinary person immersed in ordinary life situations more dangerous than crises arising in theories, and in the conceptions of which they are proposed?}

If a crisis of values is interpreted as a process that takes place in the consciousness of values, then it seems here that it would more aptly be adopted for conceptions developed in axiology or ethics. Crises of values can also manifest themselves in ways in which their status, hierarchy or any other relations between them are presented in theories. They may be variously exemplified. Relativism is one of them, another is hedonism, and still another is the position - shall I say - of naturalised 'axiology' formulated by John Leslie Mackie who concludes that values do not exist and what does are social needs that are called values as a shorthand expression. ${ }^{14}$ Psychologism may be seen as a similar example of a crisis of this type.

Are any of these crises more dangerous than others? It is impossible to answer this question in a clear and definitive way. In order to prove that

14 Cf. John Leslie Mackie, Ethics: Inventing Right and Wrong (London: Penguin Books, 1990), 15-49. 
a crisis reflected in theories is more dangerous, arguments are advanced in theories that create a semblance of validity. These - or at least equally strong arguments - are not identified in the popular consciousness. Moreover, often, as closely related to practice, it will be based on assumptions contrary to opinions that are directly, often only declaratively, voiced. The crisis of the axiological consciousness of an ordinary man is also particularly dangerous because this consciousness is the starting point of theoretical consciousness which may as a consequence easily 'inherit' the former's errors.

Two of the above-mentioned conceptions are particularly dangerous: relativism and hedonism. ${ }^{15}$ Both positions not only advance substantive arguments and proofs for their rightness (as does any other theoretical position). They also seem to be lodged in a pre-theoretical practical consciousness for which both the connection of what is valuable to the experience of pleasure and the formula 'it depends', typical of relativism, are characteristic. In other words, they both are grounded not only in theoretical arguments but also in common, everyday feelings and valuations. With respect to details, both positions will provoke other problems. Relativism prevents any conclusive assessment of conflict situations. It is also in discord with the intuition of common elementary values such as are intuited, e.g. in the face of natural disasters. Solidarity with the victims does not then have merely a relativist meaning but presupposes the existence of universally and intersubjectively acceptable values. What is extremely important is that relativism exposes man and his life full of dilemmas and emotional conflicts to 'metaphysical randomness'. How often it is that we are caught in an ethical dilemma and doubt! And yet, if relativism were right, such dilemmas would be somehow frivolous and metaphysically accidental, because they would only be a consequence of our being born in our place and time. As José Ortega y Gasset wrote, among other circumstances, 'the drama of our life would be different'. The inadequacy of the relativism of values also shows when we try to found liberal theories on it. It is impossible to vindicate liberalism by relativism as one cannot, on relativist grounds, see what values must be accepted by members of such liberal society. ${ }^{16}$

15 Although, of course, other -isms are also dangerous, such as axiological fanaticism that recognises only one particular kind of value.

16 I wrote about this more extensively in the article "Multikulturalizm, wartości oraz relatywizm lub (i) pluralizm", Idea. Studia nad Struktura i Rozwojem Pojęć Filozoficznych 28, 1 (2016): 5-21. 
Relativism, however, is not a sign of crisis for all values. Undoubtedly, it is so in relation to the majority of moral values. But is it so to all of them? Supererogative values, although their realisation arouses great respect, admiration and approval, do not have to be realised by everyone as they are by definition supererogative. Much room for relativistically discerned values is provided by 'ornamental' values, such as, for example, the value of our hobby objects or preferable colours or flavours.

Hedonism is an example of a theory in crisis for other reasons. As has been said above, recognising that hedonic values exist is not yet a fallacy or an expression of crisis. No fallacy arises as long as you do not try to reduce all other values to hedonic values. In this case a crisis occurs when hedonic values are not recognised as a specific, separate type of values. At least two major fallacies are committed at this point. The first is an appeal to nature; if the term 'value' is the same as the term 'pleasant', it is not possible - except in the realm of hedonism - to ask the sensible question: is the pleasant thing good? The second problem of the hedonist theory presents itself when in order to explain it we use Dietrich von Hildebrand's argument, according to which you are given what is pleasant through a different channel than a value. That which is pleasant is given to a person who is excited about or craving for something, whereas value is revealed to a person who experiences the discharging of a duty. Hildebrand's arguments - as I have already written in other studies - are too extreme, because his intention is to prove that what is pleasant is not a value at all. However, this argument can be effectively launched to show, though contrary to Hildebrand's intent, that hedonic values are a specific type of values, different from other types.

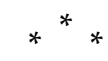

The foregoing considerations illuminate different, but theoretically equally important aspects of the issues indicated in the title of this article. From the point of view of axiology, the most valuable thing is to detect the difference between values and the consciousness of values. The value itself is thus different from its discernment or conception, from the consciousness of value. We can even say, from its cultural concretisation. It can then be reasonably and optimistically concluded that a crisis does not concern values themselves but only the consciousness of values (and their realisation).

But from the point of view of culture and our reflection on it (including the point of view of cultural philosophy) and especially in the context of 
our reflection on the sustainability of culture, the more valuable thing is the conception in which the cultural consciousness of values has the priority, because through it and within it values define human life. And this is so (which is somewhat obvious) not only when we discern values as cultural meanings existing in culture and only in it - a possible crisis of values is then only a crisis of these senses. It may also happen when values are interpreted objectively. Even in such an objective paradigm, value influences the human world through human axiological consciousness: I know about value: through this knowledge, value enters my world; moreover, it happens through my decision to realise it, through my consent to this realisation. If we could use Nicolai Hartmann's expressions, we could say that the objective values are strong because they are objective and are not subject to human interpretation. But they are also weak because they do not realise themselves in the world without the mediation of human attitudes and actions, ${ }^{17}$ or at least not without reference to human perception and sensitivity (the aesthetic value of a sunset or sunrise is brought into focus only in the context of human sensitivity).

This fact means that even if we cannot justifiably and optimistically confirm that there is no crisis of values, but there is only a crisis of the consciousness of values, then we must now say that this crisis is by no means less dangerous. The consciousness of values is the only area where values are given to us at all.

\section{Bibliography}

Baker Wayne E. 2005. America's Crisis of Values: Reality and Perception. Princeton: Princeton University Press.

Blumler Jay, Michael Gurevitch. 1995. The Crisis of Public Communication. London: Routledge.

Breczko Jacek. 2015. "Zanik uczuć metafizycznych jako przyczyna kryzysu kultury". Kultura i Wartości 13: 39-73, https://journals.umcs.pl/kw/article/ view/1715/1340, accesed: 20.05.2021.

Burckhadt Jacob. 1985. “Weltgeschichtliche Betrachtungen. Über geschichtliches Studium". In: Jacob Burckhardt, Weltgeschichtliche Betrachtungen. Historische Fragmente, ed. Johannes Wenzel. Leipzig: Dieterich'sche Verlagsbuchhandlung.

Dębowski Józef. 2005. “On Absolute Truth: K. Twardowski and W. Tatarkiewicz”. In: Polish Axiology; The 20 ${ }^{\text {th }}$ Century and Beyond, ed. Stanisław Jedynak. Washington: The Council for Research in Values and Philosophy.

17 Cf. Hartmann, Ethik, 176-182. 
Drabarek Anna. 2005. “The Conception of Goodness in Tatarkiewicz's Ethics”. In: Polish Axiology; The $20^{\text {th }}$ Century and Beyond, ed. Stanisław Jedynak. Washington: The Council for Research in Values and Philosophy.

Goździak Elżbieta, Izabella Main, Brigitte Suter (eds.). 2020. Europe and the Refugee Response: A Crisis of Values?. London: Routledge.

Hartmann Nicolai. 1958. “Das Wertproblem in der Philosophie der Gegenwart”. In: Nicolai Hartmann, Kleinere Schriften, Bd. 3: Vom Neukantianismus zur Ontologie. Berlin: Walter de Gruyter \& Co.

Hartmann Nicolai. 1962. Ethik, 4. unveränderte Auflage. Berlin: Walter de Gruyter $\&$ Co.

Kopciuch Leszek. 2015. Kryzysy, kreatywność i wartości. Lublin: Wydawnictwo UMCS.

Kopciuch Leszek. 2016. “Multikulturalizm, wartości oraz relatywizm lub (i) pluralizm". Idea. Studia nad Struktura i Rozwojem Pojęć Filozoficznych 28, 1: 5-21.

Kopciuch Leszek. 2017. “Crise of Values (Conference Report)". Kultura $i$ Wartości 24: 159-163, https://journals.umcs.pl/kw/article/view/7483/5671, accesed: 10.08.2021.

Mackie John Leslie. 1990. Ethics: Inventing Right and Wrong. London: Penguin Books.

Niebuhr Reinhold. 1954. The Cultural Crisis of Our Age. Boston: Harvard Business Review.

Nobis Adam. 2018. "The New Silk Road as a Crisis of the Value of Globalization". Kultura i Wartości 25: 9-24, doi: 10.17951/kw.2018.25.9.

Ortega y Gasset José. 1932. The Revolt of the Masses, authorized translation from the Spanish. New York: W.W. Norton \& Company.

Reiner Hans. 1964. Die philosophische Ethik. Ihre Fragen und Lehren in Geschichte und Gegenwart. Heidelberg: Quelle \& Meyer.

Schlick Moritz. 1939. Problems of Ethics, authorized translation by David Rynin. New York: Prentice-Hall, Inc.

Sorokin Pitirim. 1946. The Crisis of Our Age. The Social and Cultural Outlook. New York: New York Dutton \& Co.

Stefaniuk Tomasz. 2018. “Does Mass Culture Mean a Crisis of Values? Dwight Macdonald's Position and the Issue of Its Topicality". Kultura i Wartości 25: 25-51, doi:10.17951/kw.2018.25.25.

Tatarkiewicz Władysław. 1971. “O bezwzględności dobra” [On the Absoluteness of the Good]. In: Władysław Tatarkiewicz, Droga do filozofii. Warszawa: PWN.

Thrasher James P. 1985. A Crisis of Values: Moving from Materialism to Reality. Michigan: Michigan University.

Twardowski Kazimierz. 1994. “Etyka a teoria ewolucji”. In: Kazimierz Twardowski, Etyka. Toruń: Wydawnictwo Adam Marszałek.

Voicu Malina, Ingvill C. Mochmann, Hermann Dülmer (eds.). 2016. Values, Economic Crisis and Democracy. London-New York: Routledge. 
Wichrowski Marek. Historiozofia Pitirima Sorokina, $\mathrm{PhD}$ thesis (typescript in the archives of the Department of the History of Philosophy and Comparative Philosophy, Maria Curie-Skłodowska University in Lublin).

Witkiewicz Stanisław Ignacy. 1974. Nowe formy w malarstwie $i$ wynikajace stad nieporozumienia. In: Stanisław Ignacy Witkiewicz, Nowe formy w malarstwie. Szkice estetyczne. Teatr, ed. J. Leszczyński. Warszawa: PWN.

Znaniecki Florian. 1991. “Upadek cywilizacji zachodniej. Szkic z pogranicza filozofii kultury i socjologii". In: Florian Znaniecki, Pisma filozoficzne, Vol. 2: „Humanizm i poznanie" $i$ inne pisma filozoficzne. Warszawa: PWN.

\section{Summary}

In this article I examine some theoretical doubts about the crisis of values. Among other things, I consider the following issues: crisis of values versus crisis of value consciousness; crisis of values in general versus crisis of concrete values; negative and positive aspects of the crisis of values; and theoretical crises versus crises of practical life. The aim of the considerations is to clarify the terminology used in the theories of crisis and to answer the question as to whether we are currently experiencing a crisis of values.

Keywords: crisis, values, consciousness of values, relativism, relationism, Aristotle, Nicolai Hartmann, Moritz Schlick, Kazimierz Twardowski, Władysław Tatarkiewicz 